\title{
Production performance, egg quality characteristics and serum biochemical parameters on Brahma laying hens (Gallus gallus domesticus) fed with supplemented Chromolaena odorata leaf meal
}

\author{
M. O. S Ghomsi ${ }^{1}{ }^{2 *}$, B. L. Tientcheu ${ }^{1}$, T. G. Nguemmogne ${ }^{1}$, P. N. Bahebeck ${ }^{1}$, I. M. Nga ${ }^{1}$, M. T. \\ Chouegouong$^{1}$, M. G. Enamou', B. G. Mongo', K. C Noudio', D. S. Nya' ${ }^{1}$ and K. A. Etchu ${ }^{1}$ \\ ${ }^{1}$ Institute of Agricultural Research for Development (IRAD), BP 2067 Yaoundé, Cameroun. \\ 2Laboratory of Pharmacology and Toxicology, Department of Biochemistry, Faculty of Sciences, University of Yaoundé 1. \\ ${ }^{*}$ Corresponding author. Email: ghomsi85@gmail.com \\ Copyright @ 2021 Ismail et al. This article remains permanently open access under the terms of the Creative Commons Attribution License 4.0, which \\ permits unrestricted use, distribution, and reproduction in any medium, provided the original work is properly cited.
}

Received 24th October, 2021; Accepted 22nd November, 2021

ABSTRACT: An experiment was conducted to evaluate the effect of graded levels of Chromolaena odorata leaf meal (COLM) on production performance, egg quality characteristics, and serum biochemical parameters on Brahma laying hens. A total of forty-five local laying hens aged 4 to 5 months were weighed and assigned to three treatment groups in a completely randomized design. COLM was used as a supplement and incorporated into the diets at 0,1 , and $2 \%$ in diets $T_{0}, T_{1}$, and $T_{2}$ respectively. Data were collected on production performance, egg quality characteristics, and serum biochemistry. Results from the study indicate that body weight gain, average weight, and egg volume were low $(p<0.05)$ with treatment $T_{2}$ compared to control $\left(T_{0}\right)$ and the best was obtained with treatment $T_{1}$. The Haugh unit and percentage hen day production were not negatively affected by the treatment levels of COLM. There were significant $(p<0.05)$ differences in triglyceride, total cholesterol, and urea. Results obtained from this study revealed that the inclusion of $1 \%$ of COLM improved the egg quality as well as the health status of the birds without having any detrimental effect on the birds.

Keywords: Blood status, growth, local chicken, plant additive.

\section{INTRODUCTION}

In many parts of Africa in general and Cameroon in particular, the raising of local chickens is one of the main production activities (Fotsa, 2008; Keambou et al., 2009). These animals offer enormous economic and sociocultural advantages (Keambou et al., 2009). The local chicken represents nearly $70 \%$ of the national poultry population estimated at more than 35 million birds (INS, 2017). It contributes only about $10 \%$ to the gross domestic product and produces $1.8 \mathrm{~kg}$ of chicken meat and 20 eggs per inhabitant consumed annually (Fotsa, 2008). Unfortunately, their productivity is very low, mainly due to numerous health problems that affect their growth and reproduction. Among the pathologies encountered, bacterial infestations are very pronounced, especially in the rainy season (Fotsa et al., 2010).
Antibiotics have been used a long time ago as growth promoters because of their effectiveness in enhancing growth performance for poultry (Omidiwura et al., 2020.) Thus, to ensure satisfactory succession to antibiotics, growth promoters, it is imperative to look for substitute products with similar zootechnical effects such as probiotics, prebiotics, organic acids, clays etc. However, the production of these compounds requires sophisticated equipment; this is not within the reach of pastoralists in developing countries and hence the need to search for natural products, locally available and recoverable (Mongo et al., 2020; Pierrette Ngo et al., 2021.).

The greens (green plants of various sources) as Chromoleana Odorato Leaf Meal (COLM) have long been recognized as the cheapest and most abundant potential 
source of proteins because of their ability to synthesize amino acids from a wide range of virtually unlimited and readily available primary materials such as water, $\mathrm{CO}$, atmospheric $\mathrm{N}$ (as in legumes) (Fasuyi et al, 2005a). Many studies have shown that COLM contains anti-nutritional factors such as saponins, phytates, tannins, and cyanogenic glycosides (Fasuyi et al., 2005b; Ngozi et al., 2009). Phytic acid has been reported to bind calcium, zinc, iron, and other minerals, thereby reducing their availability in the body. Saponins reduce the uptake of certain nutrients including glucose and cholesterol at the gut through intra-lumenal physicochemical interaction. However, the anti-nutrient contents of feeds according to FAO (2018) are reduced by several processing methods including cooking, toasting, and drying (Jiwuba et al., 2018).

These shortcomings in the use of Chromolaena odorata as a feed resource for livestock notwithstanding, painstaking research efforts have found ways of tapping the vast potentials of the plant. One of these ways is by sun-drying and converting the fresh leaves to leaf meal. Sun-drying reduces the offensive odor to the barest minimum and improves palatability (Fasuyi. et al., 2005a; Aro et al., 2009). C. odorata is a scrambling perennial shrub that grows 2 to $3 \mathrm{~m}$ in height with straight, pithy, brittle stems that branch readily. The fresh leaves when applied to cuts or wounds drastically reduce bleeding (Ekenyem et al., 2010). Dried leaves of $C$. odorata are also used as mosquito repellant, as an antimicrobial agent against Bacillus cereus, and antifungal agent against Aspergillus niger. Research has also shown that they are high in crude protein, dry matter, vitamins, and minerals. C. odorata has been reported to have multipurpose medicinal properties (Tedonkeng et al., 2004). It has also been shown to possess anticancer, antidiabetic, antihepatotoxic, anti-inflammatory, antimicrobial, and antioxidant properties. The antimicrobial and antioxidative properties of $C$. odorata, necessitated the need to evaluate its effectiveness in promoting growth in broiler production (Igwe et al., 2020).

Serum biochemical analysis is an established means of assessing the toxicological, health status of animals on feeding trials since ingestion of dietary components has a measurable effect on carcass quality and may be considered as an appropriate measure of long-term nutritional status (Ghomsi et al., 2017). Therefore, this study was carried out to investigate the effect of supplemented COLM on production performance, egg physical characteristics, and some serum biochemical parameters of Brahma laying hens.

\section{MATERIALS AND METHODS}

\section{Study site and plant collection}

The trial was conducted at the experimental farm of the Institute for Research for Agricultural Development
Table 1. Proximate composition (\%) of COLM (AOAC, 2000)

\begin{tabular}{lc}
\hline Nutrients & Composition (\% DM) \\
\hline DM & 91.545 \\
EE & 8.015 \\
OM & 91.245 \\
CP & 20.585 \\
Fat & 5.4 \\
CF & 14.365 \\
CE & 4495.53 \\
ME & 2643.575 \\
\hline
\end{tabular}

DM: Dry Matter; CP: Crude Protein; ME: Metabolizable Energy; CF: Crude Fiber; EE: Ether Extract; CE: Crude Energy; OM: Organic Matter.

(IRAD), Nkolbisson. The institution is located in an area of medium-altitude (730 $\mathrm{m}$ above sea level) between $3^{\circ} 51^{\prime}$ to $3^{\circ} 53^{\prime}$ north latitude and $11^{\circ} 25^{\prime}$ to $11^{\circ} 27^{\prime}$ east longitude. The zone is an agro-ecological zone of the humid forest, characterized by an average annual temperature of $25^{\circ} \mathrm{C}$, a bimodal rainfall varying between 1500 to $2500 \mathrm{~mm} / \mathrm{year}$, and relative humidity of 70 to $90 \%$. Its climate is the Equatorial Guinean type with an average rainfall of 1600 $\mathrm{mm} /$ year (Ghomsi et al., 2017).

\section{Plant material}

The plant material for this study was leaves of Chromolaena odorata. The fresh leaves were collected during the period of April-May 2019 corresponding to the rainy season when biomass is abundant, in the campus of the Institute of Agricultural Research for Development (IRAD), Nkolbisson located in the city of Yaoundé (Central Africa).

The choice of this plant depends on its different uses, its availability and its invasiveness on the ethno-medicinal information obtained from traditional healers in certain localities. The identification of this plant was carried out at the national herbarium, IRAD. The chemical compositions of the basal feed and COLM were analyzed according to standard analytical methods (AOAC, 2000) and are shown in Table 1.

\section{Preparation of COLM}

The harvested leaves were weighed, washed with plenty of water, drained, and dried in the laboratory at room temperature $\left(22 \pm 2^{\circ} \mathrm{C}\right)$ to avoid any degradation of the active ingredients. During drying, the leaves were regularly aerated to avoid contamination by fungi. Once dried, the leaves were ground using an electric grinder and the powder was stored in plastic bags at room temperature, in a dry place, and protected from humidity and light until use.

\section{Animal material and experimental set-up}

In this study, forty-five breeding chickens (Brahma) aged 
Table 2. Calculated chemical composition of experimental diet.

\begin{tabular}{lccc}
\hline Ingredients (Kg) & $\mathbf{T}_{\mathbf{0}}$ (0\% COLM) & $\mathbf{T}_{\mathbf{1}}$ (1\% COLM) & $\mathbf{T}_{\mathbf{2}}$ (2\% COLM) \\
\hline Maize & 51.8 & 51.8 & 51.8 \\
Wheat Bran & 7 & 7 & 7 \\
Soya meal & 15 & 15 & 15 \\
Cotton seed cake & 7 & 7 & 7 \\
Fish meal & 5 & 5 & 5 \\
Oyster shell & 8 & 8 & 8 \\
Concentrate 5\% & 5 & 5 & 5 \\
Bone meal & 2 & 2 & 2 \\
Elitox & 0.1 & 0.1 & 0.1 \\
Bicalphos & 0.1 & 0.1 & 0.1 \\
Chromonla Odorata Powder & 0 & 1 & 2 \\
Total & 100 & 101 & 102 \\
& & & \\
Calculated chemical composition & & & \\
EM(Kcal/Kg) & 2673 & 2700 & 2726.5 \\
Crude Protein \% & 21.49 & 21.70 & 21.90 \\
Fat Mater & 4.11 & 4.12 & 4.13 \\
Calcium \% & 4.37 & 4.33 & 4.39 \\
Phosphorus \% & 0.78 & 0.78 & 0.77 \\
Total Lysine\% & 1.13 & 1.13 & 1.12 \\
Total Methionine & 0.47 & 0.47 & 0.47 \\
\hline
\end{tabular}

4-5 months were randomly divided into 3 groups of 15 chickens. Each group was then subdivided into 3 replicates of 5 chickens each ( 1 male and 4 females) for a total of 9 experimental units. They were reared on deep litter at a density of 5 chickens $/ \mathrm{m}^{2}$.

At this stage, a control ration ( $\left.\mathrm{T}_{0}\right)$ was made and 2 other rations containing $1 \%\left(T_{1}\right)$ and $2 \%\left(T_{2}\right)$ of COLM. Each of the 3 experimental rations was randomly allocated to the experimental units in a completely randomized design. The chemical composition of the proposed rations in the different groups is presented in Table 2. The animals were fed with the same ration plan (Table 2) and watered ad libitum. The study lasted 10 weeks (W1 to W10). Sampling was done every 7 days. The weight of the females and males was taken.

\section{Data collection}

\section{Production performance}

The birds were stabilized for 2 weeks before the starting of the study, the initial live weight of the animals was taken at the beginning of the feeding trial and weekly thereafter. The final live weight was obtained by weighing the birds at the end of the experiment. The daily weight gain, daily feed intake, and feed conversion ratio were calculated. The percentage hen-day production was computed as the percentage of the total number of eggs over the total number of days by the number of hens weekly egg production was determined by collecting eggs laid per replicate every day and pooling together for counting the total collection for seven days

\section{Egg quality measurement}

The eggs collected from each experimental unit were weighed using an electronic balance with a precision of 0.1 g. Per week, 15 eggs were randomly taken for quality testing, i.e. 5 eggs per treatment. The length $(L)$ and the large diameter (GD) of the eggs were measured with a caliper ruler to calculate the Shape Index (SI) according to the following formula: $\mathrm{Sl}=\mathrm{GD} / \mathrm{L}$. The weight of the whole egg is obtained on a precision scale. The volume of the egg was calculated by the following formula: $0.913 \mathrm{~W}$. Where $\mathrm{W}$ is the weight of the whole egg (Dilawar, 2021).

Moreover, the egg quality measurement was egg weight (g), egg mass ( $g /$ hen/day), shell weight $(g)$, albumen weight $(\mathrm{g})$, albumen height $(\mathrm{mm})$, yolk weight $(\mathrm{g})$, and Haugh unit. The tripod was used to determine the albumen height (micrometer). Each egg was taken every day regularly in fresh condition, then the egg was carefully opened to release the albumen and yolk. Then, the yolk and albumen were separated and placed in Petri dishes glasses, which had initially been weighed (Adli, 2021).

\section{Calculated parameters}

Av. weight production $/$ hen $(\mathrm{g})=\frac{\text { Total eggs weight laid }}{\text { Total hen number }}$ 
Weekly laying rate $=\frac{\text { eggs Number laid } \times 100}{\text { Total hen number }}$

Average egg weight $(\mathrm{g})=\frac{\text { Total eggs weight laid }}{\text { egg number }}$

Average egg length $(\mathrm{mm})=\frac{\text { Sum of eggs diameter laid }}{\text { Total eggs collected }}$

Aegg shape index $=\frac{\text { Average egg diameters }(\mathrm{cm})}{\text { Average egg length }(\mathrm{cm})}$

The broken or abnormal conditions in albumen and yolk such as red spots were recorded. Shell weight was weighed using an electronic scale (g). In the end, the Haugh unit was calculated by using this formula as follows (Haugh, 1937):

$H U=100 \log \left(H+7.6-1.7 W^{0.37}\right)$

Where: $\mathrm{Hu}=$ Haugh unit, $\mathrm{H}=$ observed height of the albumen in millimeter and $\mathrm{W}=$ weight of egg in grams.

\section{Blood sample collection, haematology and biochemical analysis}

At the end of the trial, the animals were starved of feed for 24 hours before blood samples were collected from one hen per replicate. For this purpose, $5 \mathrm{~mL}$ were collected with a $5 \mathrm{~mL}$ hypodermal syringe in the vacutainer without anticoagulant, from the jugular vein of each hen by veterinary technicians. Blood serum was obtained by centrifugation at $3000 \mathrm{rpm}$ for $5 \mathrm{~min}$ at $4^{\circ} \mathrm{C}$, then stored at $-80^{\circ} \mathrm{C}$ until biochemical analysis. Serum total protein was determined by the Biuret method (Gornall, et al., 1949), albumin by the Bromocresol Green (BCG) method, total cholesterol (TC) by the CHOP-PAP method. The globulin content was determined by subtracting albumin from the total protein. The other parameters measured were: highdensity lipoprotein (HDL) cholesterol, triglycerides were determined using the colorimetric enzymatic method (Trinder et al., 1969).

\section{Data analysis}

Dietary intake, mean weight gain, consumption index, were statistically analyzed using the $R$ software ( $R$ core, 2019) procedure. In case of significant difference, the averages were separated using the Duncan test. Analyses of biochemical parameters were performed using Graph Pad Prism 8.0.1 software and data were analyzed by oneway analysis of variance (ANOVA). The statistical model was as follows:

$Y i j=\mu+\alpha i+\varepsilon i j$

Where: $Y_{i j}=$ is the dependent variable (average feed consumption, initial average live weight, final average live weight, average weight gain, feed conversion), $\mu=$ general mean, $\alpha i=$ effect of treatments $\left(T_{0}, T_{1}, T_{2}\right.$ treatments $)$ and $\varepsilon i j=$ Residual error with variance $\sigma^{2}$ and $m$ mean.

\section{RESULTS}

\section{Effect of COLM on production performance of local laying hens}

The results of the production performance of Brahma local layers fed with supplemented COLM are presented in Table 3. The results show that there were no significant $(p<0.05)$ differences in final body weight, average daily weight gain, total feed intake, average daily feed intake, except the body weight gain. The hens fed with $\mathrm{T}_{1}(1 \%$ COLM)) diet had the highest mean value $(2.15 \mathrm{~kg})$ for the final body weight, followed by those of $T_{0}(2.04 \mathrm{~kg})$ diet, while the hens on diet $\left(T_{2}\right)$ had the lowest mean value $(1.92 \mathrm{~kg})$. The highest mean value for the body weight gain (0.504) was also recorded from the birds fed $\mathrm{T}_{1}$ diet, followed by the birds fed $T_{0}(0.18)$ and $T_{1}(0.10)$ diets, respectively.

\section{Egg physical characteristics of local laying hens fed with supplemented COLM}

Table 4 shows the egg quality characteristics of layers fed varying levels of COLM. The results indicate that there were significant $(p<0.05)$ differences for average weight, albumen weight, yolk weight, and volume egg. The values for average egg weight were 45.5, 46.3, and $45.1 \mathrm{~g}$ for diets 1,2 , and 3 respectively. Birds on treatment 1 with a $1 \%$ level of COLM gave the highest egg weight, surface, and length while birds on treatment 2 with the highest inclusion level $(2 \%)$ of COLM gave the smallest value than the control diet. The average egg volume gave the same value of $42.3 \mathrm{~cm}^{3}$ for treatments 1 , and a value of $41 \mathrm{~cm}^{3}$ for treatments 0 and 2. However, there was no significant statistical difference $(p<0.05)$ in the average diameter shape index and Haugh unit of the egg. The percentage of hens production and total production was significantly different $(p<0.05)$ among the eggs scored for the 2 treatment means. The highest percentage of production was obtained with hens fed with the control diet.

\section{Serum biochemical parameters on local laying hens fed with supplemented COLM}

Results of the biochemical parameters of local layers fed COLM are presented in Table 5. Results from the study indicate that there were significant differences $(p<0.05)$ in the triglyceride, total cholesterol, and urea contents while, the HDL cholesterol, and total protein had no significant difference between $T_{1}$ and $T_{2}$. Also, no significant difference between $T_{0}$ and $T_{1}$ with total protein and 
Table 3. Effect of COLM on production performance of local laying hens.

\begin{tabular}{lccccc}
\hline Variables & $\mathbf{T}_{\mathbf{0}}$ & $\mathbf{T}_{\mathbf{1}}$ & $\mathbf{T}_{\mathbf{2}}$ & $\mathbf{S E M}$ & $\mathbf{p}$ \\
\hline Initial body weight $(\mathrm{Kg})$ & 2.02 & 1.648 & 1.82 & 0.064 & 0.271 \\
Final body weight $(\mathrm{Kg})$ & 2.04 & 2.15 & 1,92 & 0.488 & 0.099 \\
Total feed intake $(\mathrm{Kg})$ & $3.73^{\mathrm{a}}$ & $3.85^{\mathrm{b}}$ & $3.71^{\mathrm{a}}$ & 0.114 & 0.019 \\
Body weight gain $(\mathrm{g})$ & 0.018 & $0.506^{\mathrm{a}}$ & $0.010^{\mathrm{b}}$ & 0.410 & $<.0001$ \\
Daily feed intake $(\mathrm{g})$ & 0.104 & 0.122 & 0.104 & 0.002 & 0.959 \\
Average Egg weight $(\mathrm{g})$ & $45.5^{\mathrm{a}}$ & $46.3^{\mathrm{ab}}$ & $45.1^{\mathrm{b}}$ & 4.55 & 0.0002 \\
Feed conversion ratio $(\mathrm{kg}$ feed/ kg egg) & $2.2^{\mathrm{a}}$ & $2.6^{\mathrm{b}}$ & $2.3^{\mathrm{a}}$ & 0.23 & 0.02 \\
\hline
\end{tabular}

abMeans in the same row without common letter are different at $\mathrm{p}<0.05$.

Table 4. Egg physical characteristics of local laying hens fed with supplemented COLM.

\begin{tabular}{lccccc}
\hline Variables & $\mathbf{T}_{\mathbf{0}}$ & $\mathbf{T}_{\mathbf{1}}$ & $\mathbf{T}_{\mathbf{2}}$ & $\mathbf{S E M}$ & $\mathbf{p}$ \\
\hline Average egg volume $\left(\mathrm{cm}^{3}\right)$ & $41.5^{\mathrm{b}}$ & $42.3^{\mathrm{a}}$ & $41.1^{\mathrm{b}}$ & 4.16 & 0.0002 \\
Average egg Diameter $(\mathrm{Cm})$ & 4,29 & 4,27 & 4,2 & 8,98 & 0,064 \\
Average egg surface $\left(\mathrm{cm}^{2}\right)$ & $59.5^{\mathrm{b}}$ & $60.2^{\mathrm{a}}$ & $59.1^{\mathrm{b}}$ & 3.92 & 0.0003 \\
Average egg length $(\mathrm{cm})$ & $5.23^{\mathrm{a}}$ & $5.21^{\mathrm{a}}$ & $5.12^{\mathrm{b}}$ & 0.35 & $<.0001$ \\
Shape index & 0,82 & 0,819 & 0,82 & 2,65 & 0,168 \\
Albumen Height $(\mathrm{mm})$ & $4.36^{\mathrm{a}}$ & $4.43^{\mathrm{b}}$ & $4.32^{\mathrm{a}}$ & 0.43 & 0.019 \\
Haugh Unit & $69.45^{\mathrm{a}}$ & $69.73^{\mathrm{b}}$ & $69.31^{\mathrm{a}}$ & 6.93 & 0.030 \\
Albumen weight $(\mathrm{g})$ & $22.94^{\mathrm{a}}$ & $23.34^{\mathrm{b}}$ & $22.73^{\mathrm{a}}$ & 2.29 & $<.0001$ \\
Yolk weight $(\mathrm{g})$ & $14.82^{\mathrm{a}}$ & $15.08^{\mathrm{b}}$ & $14.68^{\mathrm{a}}$ & 1.48 & 0.051 \\
Shell weight $(\mathrm{g})$ & $5.70^{\mathrm{a}}$ & $5.80^{\mathrm{b}}$ & $5.65^{\mathrm{a}}$ & 0.57 & 0.02 \\
Total production & $189.6^{\mathrm{a}}$ & $151.08^{\mathrm{b}}$ & $151.17^{\mathrm{b}}$ & 6.66 & 0.00015 \\
\% hens day production & $59.4^{\mathrm{a}}$ & $47.69^{\mathrm{b}}$ & $48.41^{\mathrm{b}}$ & 1.90 & 0.00029 \\
\hline
\end{tabular}

abMeans in the same row without common letter are different at $p<0.05$.

Table 5. Serum biochemical parameters on local laying hens fed with supplemented COLM.

\begin{tabular}{lccccc}
\hline Variables & $\mathbf{T}_{\mathbf{0}}$ & $\mathrm{T}_{1}$ & $\mathbf{T}_{2}$ & $\mathbf{S E M}$ & $\mathrm{p}$ \\
\hline Triglyceride $(\mathrm{mM})$ & $24.01^{\mathrm{b}}$ & $16.5^{\mathrm{a}}$ & $15.43^{\mathrm{a}}$ & 6.58 & 0.0013 \\
Total Protein $(\mathrm{g} / \mathrm{l})$ & 5.18 & 5.14 & 5.13 & 0.037 & 0.753 \\
Total Cholesterol $(\mathrm{mM})$ & $5.52^{\mathrm{a}}$ & $3.06^{\mathrm{b}}$ & $2.66^{\mathrm{b}}$ & 1.120 & 0.0002 \\
HDL Cholesterol $(\mathrm{mM})$ & $5.01^{\mathrm{a}}$ & $4.35^{\mathrm{b}}$ & $4.67^{\mathrm{b}}$ & 1.79 & 0.0002 \\
Albumin $(\mathrm{g} / \mathrm{l})$ & 3.73 & 2.77 & 4.56 & 3.09 & 0.2050 \\
Creatinin $(\mathrm{uM})$ & $82.51^{\mathrm{a}}$ & $66.77^{\mathrm{a}}$ & $104.51^{\mathrm{b}}$ & 46.14 & 0.0003 \\
Urea $(\mathrm{uM})$ & $1368^{\mathrm{a}}$ & $398.7^{\mathrm{b}}$ & $289^{\mathrm{b}}$ & 169.67 & $<.0001$ \\
\hline
\end{tabular}

abMeans in the same row without common letter are different at $p<0.05$.

creatinine. The triglyceride and total cholesterol are lower in the treatment group while the control treatment had a high level. The urea is also lower for hens fed with supplemented COLM than the control group.

\section{DISCUSSION}

This study reported a higher feed intake per bird in diet $\mathrm{T}_{1}$ and smaller for the bird in diet $T_{2}$ with the inclusion of
COLM than the control diet. Total weight gain per dietary treatment also followed the same trend. These results showed that the inclusion diet $\mathrm{T}_{1}$ was the most efficient. The finding corroborated those of Omidiwura et al. (2020), who recommended $1.5 \%$ of COLM as feed supplemented for the broiler. These results are different from other COLM studies (Fasuyi et al., 2005a; Jiwuba et al., 2018; Igwe et al., 2020), which obtained an increase in performance parameters with $5 \%$ of COLM inclusion. The decrease of performance in diet $\mathrm{T}_{2}$ could be explained by antinutritional 
factors inherent in all these plants (Fasuyi et al., 2005a; Ngozi et al., 2009).

Haugh units are indications of freshness in eggs, an index of the ability of albumen to remain viscous (Uchegbu et al., 2011). The diameter, shape index, and Haugh unit did not show any significant variation among the treatment. The highest egg weight was obtained with $\mathrm{T}_{1}$ diet means is suggestive of the equi-proteinous and iso-caloric nature of the diets and the fact that the birds were of the same age since egg weight is more of a function of the age of the birds and the quality of their feed (Okonkwo, 2020). The similar trend observed on the eggshell weight showing a slight improvement with dietary inclusion of COLM could therefore be an indication that calcium absorption and utilization, rather than being compromised in the laying hens, was improved with dietary COLM inclusion. These findings corroborated with earlier studies that the herbs included did not affect the egg quality in laying hens (Aro et al., 2009; Dilawar et al., 2021; Adli, 2021).

Blood is an important index of physiological and nutritional status in the organism (Ghomsi et al., 2017). The chemistry of serum is normally used for the diagnosis of organ diseases in farm animals and detection of the amount of available protein in the diets (Omidiwura et al., 2020). The serum biochemical results showed that COLM has no deleterious effect on serum albumin and total protein, triglyceride, HDL cholesterol, and creatinine. Serum creatinine is a measure of muscle mass. It gives the extent of catabolism of the muscular tissue and the rate of depletion of tissue creatinine phosphate (Jiwuba et al., 2017). The comparison of the value obtained with that of control showed that the inclusion of COLM up to $2 \%$ level had no catabolic effect on the muscular tissue. Serum uric acid concentration followed the trends given by red blood cell count and total feed consumed and hence total protein intake. It is therefore in consonance with literature that uric acid excretion is directly proportional to protein intake (Fasuyi et al., 2005b).

The total cholesterol is slightly lower in the treatment group while the control treatment had a high level of cholesterol. This is an indication of enzyme hydrolysis of dietary protein which demonstrated that the blood pool served as a major source of amino acids needed for the synthesis of protein. The result is in agreement with the findings of Ekenyem et al. (2010) who reported significant differences in the total cholesterol, total serum protein, and albumin of laying hens fed COLM. There was also a reduction in the total cholesterol level of the birds fed 60 $\mathrm{ml}$ of Chromolaena odorata leaf extract compared to other treatment groups that reported reductions in the total cholesterol (Igwe et al., 2020).

\section{Conclusion}

This study has demonstrated that COLM possesses good dietary quality. It could be used to improve weight gain and egg quality of Bramah laying hens. COLM can be used to supplement a diet up to a $1 \%$ inclusion level without any detrimental effect on the performance, egg quality, and serum biochemistry of laying hens.

\section{CONFLICT OF INTEREST}

The authors declare that they have no conflict of interest.

\section{ACKNOWLEDGEMENT}

The authors would like to thank the Institute of Agricultural Research for Development (IRAD) of Cameroon for funding with its Public Investment Budget and providing the necessary facilities for this work, as well as the Laboratory of Pharmacology and Toxicology of the University of Yaoundé 1 for providing biochemical kit for blood analysis.

\section{REFERENCES}

Adli, D. N. (2021). The effect of replacing fish meal with Sago larvae meal (SLM) on egg production and quality of laying hens. Livestock Research: or Rural Development, 33, Article number 94.

AOAC (2000). Official Methods of Analysis (17th Edition). The Association of Official Analytical Chemists, Gaithersburg, MD, USA.

Aro, S. O., Tewe, O. O., \& Aletor, V. A. (2009). Potentials of siam weed (Chromolaena odorata) leaf meal as egg yolk colourant for laying hens. Livestock Research for Rural Development, 21, Article number 171.

Dilawar, M. A., Mun, H. S., Rathnayake, D., Yang, E. J., Seo, Y. S., Park, H. S., \& Yang, C. J. (2021). Egg quality parameters, production performance and immunity of laying hens supplemented with plant extracts. Animals, 11(4), Article number 975.

Ekenyem, B. U., Obih, T. K. O., Odo, B. I., \& Mba, F. I. A. (2010). Performance of finisher broilers chicks fed with varying levels of Chromoneale odorata leaf for soya leaf. Pakistan Journal of Nutrition, 9(6), 558-561.

Fasuyi, A. O., Fajemilehin, S. O. K., \& Aro, S. O. (2005b). Nutritional potentials of Siam weed (Chromolaena odorata) leaf meal (SWLM) on laying hens: biochemical and haematological implications. Pakistan Journal of Nutrition, 4(5), 336-341.

Fasuyi, A. O., Fajemilehin, S. O. K., \& Omojola, A. B. (2005a). The egg quality characteristics of layers fed varying dietary inclusions of Siam weed (Chromolaena odorata) leaf meal (SWLM). International Journal of Poultry Science, 4(10), 752757.

Fotsa, J. C. (2008). Characterization of local chicken populations (Gallus gallus) in Cameroon. PASTEL - Thèses en ligne de ParisTech. p. 302.

Fotsa, J., Poné, K. D., Rognon, X, Tixier-Boichard, M., Fomunyam, D., Choupamom, J., Tchoumboué. J., Manjeli, Y, \& Bordas, A. (2010). Etudes comparees de la croissance des poules locales (Gallus Gallus) Et D'une Souche Label $\mathrm{Au}$ Cameroun. Bulletin of Animal Health and Production in Africa, 58 372-381. 
Ghomsi, M. O. S., Enow, J. T., Etchu, K. A., Tientcheu, B. L., Enamou, G., Chouengouong, T. M., Mongo, B. G, \& Bahemi, P. H. (2017). Effect of Moringa oleifera leaf meal (MOLM) on the growth, carcass, heamatology and biochemical parameters of rabbits. SOJ Veterinary Sciences, 3, 1-5.

Gornall, A. G., Bardwill, G. S., \& David, M. M. (1949). Determination of serum proteins by means of Biuret reactions. Journal of Biological Chemical, 177,751-766.

Haugh, R. R. (1937). The Haugh unit for measuring egg quality. US Egg and Poultry Magazine, 43:572-573.

Igwe, R. O., Udo, H., Ogunnupebi, J. T., Olorunleke, S. O., Aikpitanyi, K. U., \& Nwose, R. N. (2020). Efficacy of Chromolaena odorata (Siam weed) on performance, haematological and serum biochemical indices of broiler chicken. Nigerian Journal of Animal Science, 22(2), 106-113.

INS (2017). Chapitre 14: Elevage et Pêche. In: Annuaire Statistique du Cameroun (Edition 2017). Yaoundé. Cameroun. Pp. 208-219.

Jiwuba, P. C., Ogbuewu, I. P., \& Nwachukwuguru, K. (2018). Performance and economy of production of broilers fed Siam weed (Chromolaena odorata) leaf meal (SWLM). Tropical Animal Health and Production, 50(6), 1305-1311.

Jiwuba, P. C., Ogbuewu, I. P., Dauda, E., \& Azubuike, C. C. (2017). Blood profile and gut microbial load of broilers fed siam weed (Chromolaena odorata) leaf meal in their diets. Agricultura, 14(1-2), 17-24.

Keambou, T. C., Boukila, B., Moussonda, G., \& Manjeli, Y. (2009). Comparaison de la qualité des œufs et des performances de croissance des poussins locaux des zones urbaines et rurales de l'Ouest-Cameroun. International Journal of Biological and Chemical Sciences, 3(3), 457-465.

Mongo, B. G., Ghomsi, M. O. S., Tientcheu, B. L., Semi, A. Y., Menghueo, T. N., \& Etchu, K. A. (2020). Effect of coconut (Cocos nucifera) shell charcoal on the growth performance of broilers. Livestock Research for Rural Development, 32(3).

Ngozi, I. M., Jude, I. C., \& Catherine, I. C. (2009). Chemical profile of Chromolaena odorata L. (King and Robinson) leaves. Pakistan Journal of Nutrition, 8(5), 521-524.
Okonkwo, V. N. (2020). Egg quality characteristics of layer hens fed varying levels of yellow cocoyam corm meal (Xanthosoma sagittifolium) as energy source. Journal of Agriculture and Food Sciences, 18(1), 1-10.

Omidiwura, B. R. O., Agboola, A. F., Omotosho, O. Y., \& Mustapha-Olosho, J. A. (2020). Influence of diets supplemented with Carica papaya and Chromolaena odorata leaf meals on performance, blood profile and gut integrity of broiler chickens. Journal of Animal Science and Veterinary Medicine, 5(5), 173-183.

Pierrette Ngo, B., Chouegouong, T. M., Nguemmogue, G., Ghomsi, M. S. O., Tamsa, A. A., Mama, I., Enamou, M. G., Sulem, Y. N. N., \& Etchu, K. A. (2021). Evolution of cloacal bacteria and fungi in Brahma chickens (Gallus gallus domesticus) fed with Chromolaena odorata supplement. International Journal of Current Microbiology Apply Sciences 10(06), 484-496.

$\mathrm{R}$ Core Team (2019). A language and environment for statistical computing. R Foundation for Statistical Computing, Vienna, Austria.

Tedonkeng, P. E., Amvam Zollo, P. H., Tedonkeng, F., Kana, J. R., Fongang, M. D., \& Tapondjou, L. A. (2004). Compostion chimique et effet acaricide des huiles essentielles des feuilles de Chromolaena odorata (L.) King and Robins, et d'Eucalyptus saligna Smith. sur les tiques (Rhipicephalus lunulatus Neumann) de la chèvre naine de Guinée dans l'OuestCaméroun. Livestock Research for Rural Development, 16(9), Article number $71 . \quad$ Retrieved from http://www.Irrd.org/lrrd16/9/tedo16071.htm

Trinder, P. (1969). Estimation of triglyceride in blood GPO-PAP enzymatic method. American Journal of Clinical Biochemistry, 6, 24-27.

Uchegbu, M. C., Herbert, U., Ogbuewu, I. P., Nwaodu, C. H., Esonu, B. O., \& Udedibie, A. B. I. (2011). Performance and egg quality characteristics of layers fed diets containing combinations of brewers dried grains, jack bean and cassava root meal. Revista Científica UDO Agrícola, 11(1), 155-160. 